\title{
PROSEDUR PENGADAAN BARANG DAN JASA DI DINAS PENANAMAN MODAL DAN PELAYANAN TERPADU SATU PINTU DAERAH PROVINSI SULAWESI UTARA
}

\author{
Lidya Angrini Sarapi ${ }^{1}$, David P.E. Saerang ${ }^{2}$, Dhullo Afandi ${ }^{2}$ \\ ${ }^{1,2}$ Jurusan Akuntansi, Fakultas Ekonomi dan Bisnis, Universitas Sam Ratulangi, Jl. Kampus Bahu, Manado, \\ 95115, Indonesia \\ ${ }^{1}$ E-mail: lidya.sarapi@yahoo.com
}

\begin{abstract}
Procurement of goods and services that are not healthy has an impact on the losses to be borne by the community, including the low quality of services received from the government. This study aims to analyze and test the suitability of the procedures for the procurement of goods and services in the Investment and One Stop Integrated Service of North Sulawesi with Presidential Regulation Number 16 of 2018 concerning Procurement of Government Goods / Services and Government Regulation Number 60 of 2008 Government Internal Control System (GICS). The analytical method used in this study is a descriptive method that starts with collecting data to be analyzed then a conclusion is drawn and the type of research used is descriptive qualitative. The results of the study obtained that the Procedure for Procurement of Goods and Services in the Investment and One Stop Integrated Service of North Sulawesi adjusted to Government Regulation Number 16 of 2018 and Government Regulation Number 60 of 2008 has been carried out well.
\end{abstract}

Keywords: procurement; control; procedure; goods and services

\section{PENDAHULUAN}

Otonomi daerah adalah sebuah bentuk pelimpahan tugas wewenang dari pemerintah pusat kepada pemerintah daerah untuk menyelenggarakan pemerintahan yang baik dan efisien. Pemerintah sebagai stakeholders harus memiliki rasa kepekaan terhadap kepentingan dan permasalahan masyarakat yang harus dipecahkan. Pemerintah juga dituntut untuk bertanggung jawab akan setiap pelaksanaan tugasnya dan tidak melaksanakan bentuk penyalagunaan wewenang dan melampaui batas kewenangannya, ini akan menciptakan bentuk pelayanan publik yang efisien dan efektif, transparan, akuntabel.

Pemerintah dalam menjalankan fungsi, membutuhkan logistik, peralatan dan jasa yang menunjang optimalnya instansi tersebut. Kebutuhan ini dipenuhi oleh beberapa pihak, baik itu perusahaan milik pemerintah maupun swasta, pengadaan barang dan jasa di instansi pemerintah lebih rumit karena berhubungan dengan perhitungan Anggaran Pendapatan Belanja Negara/Anggaran Pendapatan dan Belanja Daerah (APBN/APBD) yang digunakan untuk membayar barang atau jasa tersebut. Pengadaan barang dan jasa juga memiliki kontribusi yang besar bagi perekonomian negara dan dalam rangka kebijakan fiskal, pengadaan barang dan jasa bertujuan untuk menyelenggarakan perekonomian dengan menumbuhkan lapangan kerja, meningkatkan daya saing, dan meningkatkan pertumbuhan ekonomi. Pengadaan barang dan jasa yang pembiayaannya baik sebagian atau seluruhnya bersumber dari APBN/APBD merupakan pengadaan barang dan jasa di lingkungan pemerintah yang bertujuan untuk menyediakan barang/jasa publik. Penyelenggaraan pengadaan barang dan jasa yang tidak sehat berdampak pada kerugian yang akan ditanggung masyarakat, termasuk rendahnya kualitas pelayanan yang diterima dari pemerintah.

Pemerintah dalam menjalankan proses pengelolaan barang milik negara, mengeluarkan aturan-aturan yang berhubungan dangan pengelolaan barang milik negara, 
diantaranya aturan proses pengadaan barang dan jasa. Aturan-aturan dimaksud berupa Peraturan Presiden Nomor 54 Tahun 2010 tentang Pengadaan Barang/Jasa Pemerintah dan sekarang sudah digantikan dengan Peraturan Presiden Nomor 16 Tahun 2018, bahwa pengadaan barang/jasa Pemerintah mempunyai peran penting dalam pelaksanaan pembangunan nasional untuk peningkatan pelayanan publik dan pengembangan perekonomian nasional dan daerah.

Pengadaan barang dan jasa dilaksanakan dengan cara swakelola dan/atau penyedia. Metode pemilihan penyedia barang/pekerjaan konstruksi/jasa lainnya terdiri dari $e$ purchasing, pengadaan langsung, penunjukan langsung, tender cepat, dan tender. Penelitian ini difokuskan pada pengadaan langsung. Pengadaan barang dan jasa yang ada di daerah diberikan kewenangan kepada pemerintah daerah untuk mengelolanya agar supaya penerapannya sesuai dengan target yang dibutuhkan oleh pemerintah daerah karena pemerintah daerah lebih mengetahui secara spesifik apa yang dibutuhkan. Akan tetapi dengan pelimpahan wewenang yang diberikan oleh pemerintah pusat kepada pemerintah daerah banyak terjadi masalah atau penyalagunaan wewenang oleh pemerintah daerah dalam pengadaan barang dan jasa, masalah yang terjadi karena kesengajaan ataupun ketidaktahuan, masalah pengadaan barang dan jasa sering terjadi antara lain mark-up dalam pengadaan barang, perbedaan spesifikasi barang, dan suap kepada pejabat pengadaan, seperti yang dilansir oleh Consumer News and Business Channel (CNBC) Indonesia menurut ketua Lembaga Kebijakan Pengadaan Barang/Jasa Pemerintah (LKPP) Roni Dwi Susanto menyatakan masalah pengadaan barang dan jasa yang sering terjadi di lingkup pemerintahan antara lain persekongkolan pengadaan, pengaturan terhadap pemenang tender, mark-up, dan kolusi antar penyedia barang hingga pengadaan fiktif (Sidik, 2019). Masalah-masalah seperti ini sering terjadi dalam lingkup pemerintahan.

\section{TINJAUAN PUSTAKA}

Akuntansi. Akuntansi didefinisikan sebagai suatu sistem informasi keuangan, yang bertujuan untuk menghasilkan dan melaporkan informasi yang relevan bagi berbagai pihak yang berkepentingan (Kartikahadi et al., 2016:3). Sedangkan Kieso et al., (2016:2), menyatakan bahwa akuntansi terdiri dari tiga kegiatan yang mendasar yaitu identifikasi, pencatatan dan pengkomunikasian peristiwa ekonomi suatu organisasi kepada pihak yang berkepentingan. Akuntansi adalah aktivitas mengumpulkan, menganalisis, menyajikan dalam bentuk angka mengklarifikasikan, mencatat, meringkas, dan melaporkan aktivitas transaksi perusahaan dalam bentuk informasi keuangan (Rudianto, 2012:16). Sujarweni (2015a:1) menyatakan bahwa akuntansi adalah suatu aktivitas jasa yang terdiri dari mencatat, mengklasifikasikan, dan melaporkan kejadian atau transaksi ekonomi yang akhirnya akan menghasilkan suatu informasi keuangan yang akan dibutuhkan oleh pihak-pihak tertentu unutk pengambilan keputusan.

Akuntansi sektor publik. Ratmono dan Mahfud (2015:7) menyatakan bahwa akuntansi sektor publik adalah proses pengidentifikasian, pengukuran, pencatatan, dan pelaporan transaksi keuangan dari entitas pemerintah daerah dalam rangka pengambilan keputusan ekonomi yang diperlukan oleh pihak eksternal. Menurut Erlina et al., (2015:2) akuntansi sektor publik adalah akuntansi yang digunakan untuk mencatat peristiwa ekonomi pada organisasi nonprofit atau nirlaba.

Akuntansi pemerintahan. Sujarweni (2015b:18) menyatakan bahwa akuntansi pemerintahan adalah akuntansi yang bersangkutan dengan bidang keuangan negara, dari anggaran sampai dengan pelaksanaan dan pelaporannya, termasuk segala pengaruh yang ditimbulkannya. Akuntansi pemerintahan merupakan bidang ilmu akuntansi yang saat ini sedang berkembang sangat pesat. Tuntutan transparansi dan akuntabilitas publik atas dana- 
dana masyarakat yang dikelola pemerintah memunculkan kebutuhan atas penggunaan akuntansi dalam mencatat dan melaporkan kinerja pemerintah (Ferina, 2016).

Sistem akuntansi pemerintahan. Sistem Akuntansi Pemerintahan menurut Peraturan Pemerintah Nomor 71 Tahun 2010 tentang Standar Akuntansi Pemerintahan adalah rangkaian sistematik dari prosedur, penyelenggara, peralatan, dan elemen lain untuk mewujudkan fungsi akuntansi sejak analisis transaksi sampai dengan pelaporan keuangan di lingkungan organisasi pemerintah.

Prosedur pengadaan barang dan jasa sampai dengan penerimaan barang. Prosedur pengadaan barang dan jasa sampai dengan penerimaan barang di Dinas Penanaman Modal dan Pelayanan Terpadu Satu Pintu Daerah Provinsi Sulawesi Utara (DPMPTSP) dimulai dengan pemilihan Peraturan Menteri Keuangan Republik Indonesia Nomor 238/PMK.05/2011 pasal 1, sistem akuntansi pemerintahan adalah rangkaian sistematik dari prosedur, penyelenggara, peralatan dan elemen lain untuk mewujudkan fungsi akuntansi sejak analisis transaksi sampai dengan pelaporan keuangan di lingkungan organisasi pemerintah.

Pengadaan barang dan jasa. Definisi pengadaan barang dan jasa secara harafiah menurut Kamus Besar Bahasa Indonesia (KBBI), yaitu berarti tawaran untuk mengajukan harga dan memborong pekerjaan atas penyediaan barang dan jasa. Berdasarkan definisi tersebut timbul pengertian bahwa ada dua pihak yang berkepentingan. Pihak pertama instansi pemerintah, Badan Usaha Milik Negara (BUMN), atau perusahaan swasta yang mengadakan penawaran pengadaan barang dan jasa. Pihak kedua personal atau perusahaan kontraktor yang menawarkan diri untuk memenuhi permintaan akan pengadaan barang dan jasa tersebut.

Prosedur pengadaan barang dan jasa. Prosedur pengadaan barang dan jasa adalah urutan-urutan proses pengadaan barang yang berperan penting untuk kelancaran kinerja seluruh aktivitas yang berjalan dari suatu instansi pemerintah atau swasta. Akan tetapi, setiap instansi memiliki standarisasi yang berbeda dalam prosedur pengadaan barang.

Sistem pengendalian internal. Mulyadi (2016:129) menyatakan bahwa sistem pengendalian internal meliputi struktur organisasi, metode dan ukuran-ukuran yang digabungkan untuk melindungi aset organisasi, memeriksa ketelitian dan keandalan data akuntansi, mendorong efisiensi dan mendorong dipatuhinya kebijakan manajemen. Pengendalian internal disebut juga sebuah kerangka kerja terintegrasi adalah sebuah standar yang digunakan perusahaan dalam mendesain, menganalisis, dan mengevaluasi pengendalian internal (Warren et al., 2015:400). Menurut Sujarweni (2015:69), sistem pengendalian internal adalah suatu sistem yang dibuat untuk memberi jaminan keamanan bagi unsur-unsur yang ada dalam perusahaan.

Tujuan sistem pengendalian internal. Menurut Sujarweni (2015:69), tujuan perusahaan membuat sistem pengendalian internal adalah sebagai berikut: (1) untuk menjaga kekayaan organisasi; (2) untuk menjaga keakuratan laporan keuangan perusahaan; (3) untuk menjaga kelancaran operasi perusahaan; (4) untuk menjaga kedisiplinan dipatuhinya kebijakan manajemen; dan (5) agar semua lapisan yang ada di perusahaan tunduk pada hukum dan aturan yang sudah ditetapkan di perusahaan. Menurut Tuanakotta (2015:94), tujuan dari pengendalian internal secara garis besar dapat dibagi ke dalam empat kelompok yaitu: (1) tujuan strategis, dimana dengan sasaran-sasaran utama yang mendukung misi entitas; (2) tujuan pelaporan keuangan, agar laporan keuangan bebas dari salah saji material, tepat waktu dan tepat guna; (3) tujuan operasional, dimana pengendalian mengamankan operasi entitas yang dikenal sebagai operasional control; dan (4) tujuan kepatuhan, terhadap hukum dan ketentuan perundang-undangan.

Sistem Pengendalian Internal Pemerintah. Menurut Peraturan Pemerintah Nomor 60 Tahun 2008 tentang Sistem Pengendalian Intern Pemerintah (SPIP), bahwa sistem pengendalian intern pemerintah adalah proses yang integral pada tindakan dan kegiatan yang 
dilakukan secara terus-menerus oleh pimpinan dan seluruh pegawai untuk memberikan keyakinan memadai atas tercapainya tujuan organisasi melalui kegiatan yang efektif dan efisien, keandalan pelaporan keuangan, pengamanan aset negara dan ketaatan terhadap peraturan perundang-undangan. SPIP adalah sistem pengendalian intern yang diselenggarakan secara menyeluruh dilingkungan pemerintah pusat dan pemerintah daerah. SPIP bertujuan untuk memberikan keyakinan yang memadai bagi tercapainya efektivitas dan efisiensi pencapaian tujuan penyelenggaraan pemerintahan negara, keandalan pelaporan keuangan, pengamanan aset negara, dan ketaatan terhadap peraturan perundang-undangan.

Unsur-unsur Sistem Pengendalian Intern Pemerintah. Adapun unsur-unsur dalam sistem pengendalian intern pemerintah, yaitu:

1. Lingkungan pengendalian

a. Penegakan integritas dan nilai etika.

b. Komitmen terhadap kompetensi.

c. Kepemimpinan yang kondusif.

d. Pembentukan struktur organisasi yang sesuai dengan kebutuhan.

e. Pendelegasian wewenang dan tanggung jawab yang tepat.

f. Penyusunan dan penerapan kebijakan yang sehat tentang pembinaan sumber daya manusia.

g. Perwujudan peran aparat pengawasan intern pemerintah yang efektif.

h. Hubungan kerja yang baik dengan instansi pemerintah yang terkait.

2. Penilaian risiko

Penilaian risiko pemimpin instansi pemerintah menetapkan tujuan instansi pemerintah dan tujuan pada tingkat kegiatan dengan berpedoman pada peraturan perundangundangan. Tujuan instansi pemerintah memuat pernyataan dan arahan yang spesifik, terukur dapat dicapai, realistis dan terikat waktu.

3. Kegiatan pengendalian

a. Reviu atas kinerja instansi pemerintah yang bersangkutan.

b. Pembinaan sumber daya manusia.

c. Pengendalian atas pengelolaan sistem informasi.

d. Pengendalian fisik atas asset. Penetapan dan reviu atas indikator dan ukuran kinerja.

e. Pemisahan fungsi.

f. Otoritas atas transaksi dan kejadian yang penting.

g. Pencatatan yang akurat dan tepat waktu atas transaksi dan kejadian.

h. Pembatasan akses atas sumber daya dan pencatatannya.

i. Akuntabilitas terhadap sumber daya dan pencatatannya.

j. Dokumentasi yang baik atas atas sistem pengedalian intern serta transaksi dan kejadian yang penting.

4. Informasi dan komunikasi

a. Menyediakan dan memanfaatkan berbagai bentuk dan sarana komunikasi.

b. Mengelola, mengembangkan dan memperbaharui sistem informasi secara terus menerus.

5. Pemantauan pengendalian intern

Pemantauan Pengendalian intern dilaksanakan melalui pemantauan berkelanjutan, evaluasi terpisah, dan tindak lanjut rekomendasi hasil audit dan reviu lainnya.

\section{METODE PENELITIAN}

Jenis penelitian ini menggunakan penelitian kualitatif dengan pendekatan analisis deskriptif. Penelitian kualitatif sebagai prosedur penelitian yang menghasilkan data deskriptif berupa kata-kata tertulis atau lisan yang dihasilkan dari studi kasus dengan cara melakukan pengamatan secara detail kepada objek penelitian yaitu di Dinas Penanaman Modal dan 
Pelayanan Terpadu Satu Pintu Daerah Provinsi Sulawesi Utara yang beralamat di Jln. Sam Ratulangi No. 103 A Kota Manado, waktu penelitian dilakukan pada bulan Februari sampai Mei 2020.

Jenis Data yang digunakan dalam penelitian ini yaitu data kualitatif deskriptif. Data kualitatif berupa uraian dan penjelasan mengenai prosedur pengadaan barang dan jasa di Dinas Penanaman Modal dan Pelayanan Terpadu Satu Pintu Daerah Provinsi Sulawesi Utara sesuai dengan peraturan perundang-undangan. Sumber data yang dipakai dalam penelitian ini berupa data primer yaitu penelitian ini langsung mendapatkan data dari sumber data di Dinas Penanaman Modal dan Pelayanan Terpadu Satu Pintu Daerah Provinsi Sulawesi Utara. Metode pengumpulan data yang digunakan yaitu wawancara dan dokumentasi. Metode analisis yang digunakan dalam penelitian ini adalah metode analisis deskriptif. Metode analisis dimulai dengan langkah menggumpulkan dan menyaring keterangan-keterangan yang diperoleh secara menyeluruh dan detail kemudian diuraikan sehingga diperoleh gambaran yang jelas. Adapun analisis yang digunakan pada penelitian adalah analisis kepatuhan dan analisis pengendalian internal.

\section{HASIL PENELITIAN DAN PEMBAHASAN}

\subsection{Hasil penelitian}

Organisasi pengadaan barang dan jasa di Dinas Penanaman Modal dan Pelayanan

Terpadu Satu Pintu Daerah Provinsi Sulawesi Utara. Organisasi yang terkait dalam pengadaan barang dan jasa pemerintah di Dinas Penanaman Modal dan Pelayanan Terpadu Satu Pintu Daerah Provinsi Sulawesi Utara sebagai berikut;

1. Pengguna Anggaran (PA). Pengguna anggaran adalah pejabat pemegang kewenangan pengguna anggaran Kementerian Negara/Lembaga/Perangkat Daerah. Pengguna anggaran di DPMPTSP yaitu Kepala Dinas Bapak Fransiscus E. Manumpil.

2. Pejabat Pembuat Komitmen (PPK). Pejabat pembuat komitmen adalah pejabat yang diberi kewenangan oleh PA untuk mengambil keputusan dan/atau melakukan tindakan yang dapat mengakibatkan pengeluaran anggaran belanja daerah. Pejabat pembuat komitmen di DPMPTSP yaitu Bapak Denny Tirajoh.

3. Pejabat Pemeriksaan Hasil Pekerjaan (PjPHP). Pejabat pemeriksaan hasil pekerjaan (PjPHP) memiliki tugas memeriksa administrasi hasil pekerjaan pengadaan barang/pekerjaan konstruksi/jasa lainnya yang bernilai paling banya Rp 200.000.000-, dan Jasa Konsultasi yang bernilai paling banyak Rp 100.000.000-,. PjPHP di DPMPTSP bertugas untuk memeriksa seluruh surat-surat yang terkait dalam pengadaan barang dan jasa. Pejabat pemeriksaan hasil pekerjaan yaitu Bapak Novie Supit.

4. Pejabat Pengelola Teknis Kegiatan (PPTK). Pejabat pengelola teknis kegiatan membuat surat permohonan kepada pengguna anggaran untuk melaksanakan pengadaan barang dan jasa yang dibutuhkan DPMPTSP. Pejabat pengelola teknis kegiatan di DPMPTSP disetiap bidang memiliki PPTK.

5. Pengurus Barang. Pengurus barang menerima barang yang selesai diadakan kemudian menyimpan barang tersebut. Jika barang tersebut akan dipakai pihak pemakaian barang membuat surat kepada Kelapa Dinas untuk bisa mengeluarkan barang dan diserahkan kepada pihak yang akan memakai barang tersebut. Pengurus Barang di DPMPTSP yaitu Ibu Windy Suwuh.

Prosedur Permintaan Pengadaan Barang dan Jasa sampai Persetujuan Pengadaan Barang dan Jasa. Prosedur permintaan pengadaan barang dan jasa sampai dengan persetujuan pengadaan barang dan jasa di DPMPTSP dimulai dengan kegiatan perencanaan kebutuhan akan barang dan jasa sampai dengan disetujui atau ditolaknya permintaan atas pengadaan barang dan jasa tersebut: 
1. Pejabat Pengelola Teknis Kegiatan (PPTK): Membuat surat permohonan kepada pengguna anggaran untuk melaksanakan pengadaan barang dan jasa.

2. Pengguna Anggaran (PA)/Kuasa Pengguna Anggaran (KPA): Menerima surat permohonan dari PPTK, selanjutnya memerintahkan kepada PPK untuk menugaskan pejabat pengadaan.

3. Pejabat Pembuat Komitmen (PPK): PPK mengeluarkan surat permintaan pelaksanaan pengadaan barang dan jasa ditujukan kepaa pejabat pengadaan.

4. Pejabat Pengadaan: Memilih penyedia dan mengeluarkan surat permintaan pemesanan yang ditandatangani pejabat pengadaan mengetahui PPK.

Prosedur pengadaan barang dan jasa sampai dengan penerimaan barang. Prosedur pengadaan barang dan jasa sampai dengan penerimaan barang di DPMPTSP dimulai dengan pemilihan penyedia dan pengeluaran surat permintaan pemesanaan yang ditandatangani oleh pejabat pengadaan menegetahui PPK sampai dengan hasil pekerjaan yang telah sesuai dengan administrasi hasil pekerjaan atas pengadaan barang dan jasa tersebut.

1. Pejabat Pengadaan: Memilih penyedia dan mengeluarkan surat permintaan pemesanan yang ditandatangani pejabat pengadaan mengetahui PPK.

2. Hasil Pengadaan: Semua barang yang dimohonkan bila telah memenuhi syarat dan administrasi akan diproses untuk diadakan sesuai dengan spesifikasi barang/jasa yang sudah dimohonkan.

3. Pejabat Pembuat Komitmen (PPK): PPK menerima hasil pekerjaan dan memuat/menandatangani Berita Acara Serah Terima Hasil Pekerjaan (BAST).

4. Pejabat Pemeriksaan Hasil Pekerjaan (PjPHP): Memeriksa administrasi hasil pekerjaan.

\subsection{Pembahasan}

Analisis kepatuhan terhadap pembentukan organisasi pengadaan barang dan jasa di Dinas Penanaman Modal dan Pelayanan Terpadu Satu Pintu Daerah Provinsi Sulawesi Utara. Berdasarkan uraian pada hasil penelitian yang dilakukan bahwa pada Dinas Penanaman Modal dan Pelayanan Terpadu Satu Pintu Daerah Provinsi Sulawesi Utara memiliki organisasi/pelaku pengadaan untuk mengadakan barang dan jasa sebagai berikut; Pengguna Anggaran (PA) yang tugas dan kewenangannya diatur pada Peraturan Presiden Nomor 16 Tahun 2018 pasal 9 ayat (1) tentang tugas dan kewenangan PA. Pengguna anggaran menjalankan tugasnya untuk menetapkan Pejabat Pembuat Komitmen (PPK) dan menetapkan Pejabat Pemeriksaan Hasil Pekerjaan (PjPHP) sesuai PERPRES No. 16 Tahun 2018 pasal 9 ayat (1)g dan (1)i. Pelaku pengadaan barang dan jasa selanjutnya sesuai yang ditetapkan oleh pengguna anggaran adalah Pejabat pembuat komitmen yang tugas dan kewenangannya diatur dalam Peraturan Presiden Nomor 16 Tahun 2018 pasal 11 ayat (1) tentang tugas PPK dan PjPHP yang tugas dan kewengannya diatur dalam Peraturan Presiden Nomor 16 Tahun 2018 pasal 15 ayat (1) tentang tugas PjPHP. Selanjutnya organisasi/pelaku pengadaan di DPMPTSP adalah pejabat pengelola teknis kegiatan dan pengurus barang. Berdasarkan hasil pengujian atas kepatuhan organisasi/pelaku pengadaan barang dan jasa diatas bahwa organisasi/pelaku pengadaan barang dan jasa sudah sesuai dengan PERPRES Nomor 16 Tahun 2018 pasal 8.

Analisis kepatuhan prosedur permintaan pengadaan barang dan jasa sampai persetujuan pengadaan barang dan jasa di Dinas Penanaman Modal dan Pelayanan Terpadu Satu Pintu Daerah Provinsi Sulawesi Utara. Berdasarkan hasil penelitian pada bagian sebelumnya, yang ada tentang prosedur permintaan pengadaan barang dan jasa sampai persetujuan pengadaan barang dan jasa di Dinas Penanaman Modal dan PTSP Daerah Provinsi Sulawesi Utara akan diuji kepatuhannya apakah prosedur tersebut dilaksanakan sesuai Peraturan Presiden Nomor 16 Tahun 2018 tentang Pengadaan Barang/Jasa. Peraturan Presiden Nomor 16 Tahun 2018 tidak mengatur kedudukan, tugas dan fungsi dari PPTK. 
Oleh karena itu penelitian ini langsung membahas proses tahapan pengguna anggaran yang menerima surat dari pejabat pelaksanaan teknis kegiatan dan memerintahkan kepada pejabat pembuat komitmen untuk menugaskan pejabat pengadaan. Prosedur selanjutnya, pejabat pembuat komitmen mengeluarkan surat permintaan pelaksanaan pengadaan barang/jasa ditujukan kepada pejabat pengadaan sampai dengan proses akhir yaitu pejabat pengadaan memilih penyedia dan mengeluarkan surat permintaan pemesanan yang ditandatangani pejabat pengadaan mengetahui pejabat pembuat komitmen. Tahapan prosedur diatas selanjutnya dilihat kesesuaiannya dengan prosedur yang diatur dalam Peraturan Presiden Nomor 16 Tahun 2018 tentang Pengaaan Barang/Jasa Pemerintah. Oleh sebab itu prosedur yang ada pada Dinas Penanaman Modal dan PTSP Daerah Provinsi Sulawesi Utara terutama yang berhubungan dengan tugas yang dilakukan oleh pengguna anggaran sudah sesuai dengan Peraturan Presiden Nomor 16 Tahun 2018 pada pasal 9 ayat (1) sampai ayat (3). Demikian pula halnya dengan tugas dan kewenangan kemudian prosedur yang dilaksanakan oleh pejabat pembuat komitmen telah sesuai dengan acuan Peraturan Presiden Nomor 16 Tahun 2018 pada pasal 11 ayat (1) sampai ayat (3) yang mengatur bahwa ; tugas dan kewenangan PPK dalam pengadaan barang dan jasa. Tahapan selanjutnya surat permintaan pelaksanaan pengadaan barang dan jasa diberikan kepada pejabat pengadaan untuk memilih penyedia dan mengeluarkan surat permintaan pemesanan yang ditandatangani oleh pejabat pengadaan dan diketahui oleh pejabat pembuat komitmen. Berdasarakan hasil pengujian atas kepatuhan prosedur permintaan pengadaan barang dan jasa sampai dengan persetujuan pengadaan barang dan jasa diatas, tidak terdapat rangkaian prosedur yang diatur dalam Peraturan Presiden Nomor 16 Tahun 2018 tidak dipatuhi. Demikian prosedur permintaan pengadaan barang dan jasa sampai dengan persetujuan pengadaan barang dan jasa di Dinas Penanaman Modal dan Pelayanan Terpadu Satu Pintu Daerah Provinsi Sulawesi Utara telah dilaksanakan sesuai dengan peraturan perundang-undangan.

Analisis kepatuhan prosedur pengadaan barang dan jasa sampai penerimaan barang di Dinas Penanaman Modal dan Pelayanan Terpadu Satu Pintu Daerah Provinsi Sulawesi Utara. Berdasarkan hasil penelitian pada bagian sebelumnya tentang prosedur pengadaan barang dan jasa sampai penerima barang di Dinas Penanaman Modal dan PTSP Daerah Provinsi Sulawesi Utara akan diuji kepatuhannya apakah prosedur tersebut dilaksanakan sesuai atau tidak dengan Peraturan Presiden Nomor 16 Tahun 2018 tentang Pengadaan Barang/Jasa Pemerintah. Kesesuaian dimaksud, yakni menelaah setiap tahapan prosedur yang dilakukan oleh Pejabat pengadaan sampai dengan ditandatanganinya berita acara serah terima hasil pekerjaan. Pengujian ini untuk menguji apakah pejabat pembuat komitmen telah menjalankan tugas dan tanggung jawab sesuai dengan Peraturan Presiden Nomor 16 Tahun 2018 pasal 11 ayat (1) sampai ayat (3) yang mengatur tugas dan tanggung jawab PPK dan menguji pejabat penerima hasil pekerjaan dalam menjalankan tugasnya sesuai atau tidak dengan Peraturan Presiden Nomor 16 Tahun 2018 pasal 15 ayat (1) tentang tugas PjPHP. Merujuk pada hasil pengujian diatas tentang kepatuhan prosedur pengadaan barang dan jasa sampai dengan penerimaan barang apakah sesuai dengan Peraturan Presiden Nomor 16 tahun 2018 pasal 57 dan pasal 58 tentang serah terima hasil pekerjaan. Pengujian diatas dari hasil penelitian tentang prosedur pengadaan barang dan jasa sampai dengan penerimaan barang di Dinas Penanaman Modal dan PTSP Daerah Provinsi Sulawesi Utara, maka tidak terdapat rangkaian prosedur yang tidak dipatuhi sehingga prosedur pengadaan barang dan jasa sampai dengan penerimaan barang sudah sesuai dengan peraturan perundangundangan. 


\section{Analisis sistem pengendalian intern atas prosedur pengadaan barang dan jasa di Dinas Penanaman Modal dan Pelayanan Terpadu Satu Pintu Daerah Provinsi Sulawesi Utara.}

1. Lingkungan pengendalian. Lingkungan pengendalian menjelaskan dan menguraikan bagaimana prosedur atau kebijakan yang bisa menggambarkan kegiatan kerja pimpinan dan pegawai dalam pencapaian suatu tujuan yang menjadi fondasi dalam 4 komponen sistem pengendalian intern pemerintah yang lain. Kegiatan seluruh pegawai yang berkaitan dengan pengadaan barang dan jasa diatur sesuai dengan mekanisme atau proses yang sudah ada agar penerapannya tidak terjadi kesalahan supaya tidak ada yang dirugikan. Kinerja pegawai yang terlibat dalam proses pengadaan barang dan jasa sudah dibagi uraian tugasnya masing-masing sesuai dengan kompetensinya atau dasar pendidikannya. Pegawai yang mengurus pengadaan barang dan jasa harus memahami dengan baik bagaimana proses pengadaan barang dan jasa. Pimpinan melakukan penilaian kepada pegawai yang kemungkian akan terlibat dalam proses pengadaan barang dan jasa, pejabat pembuat komitmen harus sudah mengikuti dan lulus dalam ujian pengadaan barang dan jasa dibuktikan dengan memiliki sertifikat. Proses pengadaan barang dan jasa perlu adanya interaksi antar pihak mulai dari Kepala Sub Bagian yang juga sebagai pejabat pengelola teknis kegiatan agar supaya proses pengadaan barang dan jasa terstruktur.

2. Penilaian risiko. Penilaian risiko terhadap prosedur pengadaan barang dan jasa di Dinas Penanaman Modal dan Pelayanan Terpadu Satu Pintu Daerah Provinsi Daerah Sulawesi Utara dimulai dari Kepala Sub Bagian sebagai pejabat pengelola teknis kegiatan membuat surat permohonan yang isinya daftar barang yang dimohonkan kepada Kepala Dinas selaku pengguna anggaran kemudian Kepala Dinas berkoordinasi dengan pejabat pembuat komitmen untuk mengeluarkan surat permintaan pelaksaan pengadaan barang dan jasa yang ditujukan kepada pejabat pengadaan, selanjutnya pejabat pengadaan memilih penyedia dan mengeluarkan surat permintaan pemesanan yang ditandatangani pejabat pengadaan mengetahui PPK, ini kemudian bisa dianalisa kemungkinankemungkinan risiko yang akan terjadi seperti risiko mengenai lebihnya dana yang akan dikeluarkan dan ada barang yang tidak sesuai spesifikasinya. Penilaian risiko dilakukan dengan memeriksa setiap aktivitas atau kegiatan untuk memastikan tidak ada penyimpangan yang terjadi, karena menurut narasumber kesalahan yang pernah terjadi dalam proses pengadaan barang dan jasa adalah barang yang datang tidak sesuai dengan spesifikasi yang dimohonkan. Oleh karena itu penilaian risiko di DPMPTSP saat ini diterapkan dengan baik ini dilakukan terhadap internal maupun eksternal.

3. Kegiatan pengendalian. Kegiatan pengendalian sudah diterapkan tujuannya untuk mengontrol setiap kegiatan yang berlangsung terlebih khusus kegiatan proses pengadaan barang dan jasa. Terdapat kebijakan atau prosedur yang dilakukan untuk mempermudah dalam berbagai tindakan ketika mengalami risiko yang muncul dan baru teridentifikasi seperti dilakukan reviu atau pemeriksaan terhadap kinerja, dengan berdasarkan pada standar kinerja yang telah ditetapkan sebelumnya. Kegiatan pengendalian diterapkan untuk mempermudah pencapaian tujuan, oleh kerena itu adanya komunikasi antar pegawai atau yang terkait mengenai visi, misi dan tujuan dari Dinas Penanaman Modal dan Pelayanan Terpadu Satu Pintu Daerah Provinsi Sulawesi Utara, untuk mempermudah kegiatan pengendalian ada aplikasi yang dibuat demi kelancaran dan keamanan dokumen dalam proses pengadaan barang dan jasa, aplikasi Sistem Informasi Manajemen Daerah (SIMDA) barang merupakan aplikasi untuk menunjang pegawai dalam mengontrol barang yang telah diadakan.

4. Informasi dan komunikasi. Informasi dan komunikasi memiliki pengaruh yang besar terhadap berbagai aktivitas yang ada terlebih dalam proses pengadaan barang dan jasa, 
informasi dan komunikasi dan bersangkutan harus diidentifikasi, tergambar dan terkomunikasi dengan baik dalam sebuah form dan timeframe yang memungkinkan orang-orang yang menjalankan tanggung jawabnya. Tanpa adanya komunikasi kegiatan yang sudah disusun tidak akan berjalan dengan baik. Program atau kegiatan di Dinas Penanaman Modal dan Pelayanan Terpadu Satu Pintu Daerah Provinsi Sulawesi Utara akan sangat baik apabila pihak yang terlibat dapat berkomunikasi serta memberikan informasi dengan baik. Berdasarkan hasil wawancara mengenai informasi dan komunikasi bersama dengan narasumber WS selaku pengurus barang, informasi dan komunikasi di Dinas Penanaman Modal dan Pelayanan Terpadu Satu Pintu Daerah Provinsi Sulawesi Utara sudah dilaksanakan dengan cukup baik, semua pegawai yang terlibat dalam proses pengadaan barang dan jasa memanfaatkan berbagai bentuk sarana dalam berkomunikasi misalnya dalam penggunaan media whatsapp dan via telepon. Ada juga sistem informasi seperti LPSE (Lembaga Pengadaan Secara Elektronik) yang bisa diakses melalui internet untuk mempermudah pengguna anggaran dalam mengumumkan Rencana Umum Pengadaan (RUP).

5. Pemantauan pengendalian. Pemantauan pengendalian sudah dilakukan kembali atau pengecekan dan evaluasi terhadap pengadaan barang dan jasa yang telah terlaksana, ada juga pihak ketiga atau ekstern pemerintah yang dilibatkan dalam pelaksanaan pemantauan pengendalian intern seperti inspektorat. Kegiatan pemantauan yang bertujuan untuk memantau atau mengawasi setiap pergerakan dari setiap kegiatan atau program yang sudah direncanakan. Pemantauan pengendalian intern yang ada di Dinas Penanaman Modal dan Pelayanan Terpadu Satu Pintu Daerah Provinsi Sulawesi Utara sudah cukup baik karena telah melibatkan semua pihak baik yang melaksanakan maupun yang memeriksa.

\section{KESIMPULAN DAN SARAN}

\subsection{Kesimpulan}

Berdasarkan hasil penelitian dan pembahasan mengenai prosedur pengadaan barang dan jasa, dapat diambil kesimpulan sebagai berikut:

1. Pembentukan organisasi pengadaan barang dan jasa pada Dinas Penanaman Modal dan Pelayanan Terpadu Satu Pintu Daerah Provinsi Sulawesi Utara telah sesuai dengan Peraturan Presiden Nomor 16 Tahun 2018 tentang Pengadaan Barang/Jasa Pemerintah.

2. Prosedur permintaan pengadaan barang dan jasa sampai persetujuan pengadaan barang dan jasa yang dilakukan oleh Dinas Penanaman Modal dan Pelayanan Terpadu Satu Pintu Daerah Provinsi Sulawesi Utara telah dilaksanakan sesuai dengan peraturan perundangundangan yang berhubungan dengan kebijakan pengadaan barang dan jasa.

3. Prosedur pengadaan barang dan jasa sampai penerima barang yang dilakukan oleh Dinas Penanaman Modal dan Pelayanan Terpadu Satu Pintu Daerah Provinsi Sulawesi Utara telah dilaksanakan sesuai dengan peraturan perundang-undangan yang berhubungan dengan kebijakan pengadaan barang dan jasa.

4. Sistem pengendalian intern atas prosedur permintaan pengadaan barang dan jasa sampai persetujuan pengadaan barang dan jasa dan prosedur pengadaan barang dan jasa sampai penerima barang yang dilakukan oleh Dinas Penanaman Modal dan Pelayanan Terpadu Satu Pintu Daerah Provinsi Sulawesi Utara sudah cukup baik dan memadai, akan tetapi masih terdapat yang harus ditingkatkan pelaksanaannya yaitu penilaian risiko, terutama kegiatan yang berhubungan dengan proses membedakan spesifikasi barang yang diterima dan barang yang dimohonkan.

\subsection{Saran}

Berdasarkan hasil penelitian dan pembahasan diketahui bahwa dalam menganalisis pembentukan organisasi dan prosedur pengadaan barang dan jasa ada beberapa hal yang 
harus diperhatikan dalam prosedur permintaan pengadaan barang dan jasa sampai persetujuan pengadaan barang dan jasa, dan prosedur pengadaan barang dan jasa sampai penerimaan barang seperti koordinasi antar pegawai yang terlibat dalam proses barang dan jasa untuk menciptakan pekerjaan yang baik dan memberikan pelatihan yang berkelanjutan untuk menambah wawasan setiap pegawai yang terlibat dalam proses pengadaan barang dan jasa dan kemudian harus adanya evaluasi untuk mengukur ketercapaian. Memperhatikan beberapa hal tersebut bisa mengatasi masalah yang ada seperti perbedaan spesifikasi barang yang diterima dan barang yang dimohonkan selain itu juga pihak pengguna barang dan jasa diharapkan mempergunakan barang dan jasa yang telah disediakan dengan sebaik mungkin.

\section{DAFTAR PUSTAKA}

Erlina., Rambe, O. S., \& Rasdianto. (2015). Akuntansi keuangan daerah berbasis akrual. Jakarta: Salemba Empat.

Ferina, I. S. (2016).Tinjauan kesiapan pemerintah desa dalam implementasi Peraturan Menteri Dalam Negeri Nomor 113 tentang Pengelolaan Keuangan Desa (studi kasus pada pemerintah desa di Kabupaten Ogan Hir). Jurnal Manajemen dan Bisnis Sriwijaya, $\quad$ 14(3), 321-336. https://ejournal.unsri.ac.id/index.php/jmbs/article/view/3991

Kartikahadi, H., Sinaga, R. U., Syamsul, M., Siregar, S. V., \& Wahyuni, E. T. (2016). Akuntansi keuangan berdasarkan SAK berbasis IFRS Buku 1. Jakarta: Salemba Empat.

Kieso, D. E., Weygandt, J. J., \& Warfield, T. D. (2016). Intermediate accounting IFRS. Second Edition. United States: Wiley.

Mulyadi. (2016). Sistem informasi akuntansi. Jakarta: Salemba Empat.

Peraturan Menteri Keuangan Republik Indonesia Nomor 238/PMK.05/2011 tentang Pedoman Umum Sistem Akuntansi Pemerintahan. Berita Negara Republik Indonesia Tahun 2011 Nomor 899. Jakarta.

Peraturan Pemerintah Nomor 60 Tahun 2008 tentang Sistem Pengendalian Intern Pemerintah. Lembaran Negara Republik Indonesia Tahun 2008 Nomor 127. Jakarta.

Peraturan Pemerintah Nomor 71 Tahun 2010 tentang Standar Akuntansi Pemerintahan. Lembaran Negara Republik Indonesia Tahun 2010 Nomor 123. Jakarta.

Peraturan Presiden Nomor 16 Tahun 2018 tentang Pengadaan Barang/Jasa Pemerintah. 16 Maret 2018. Lembaran Negara Republik Indonesia Tahun 2018 Nomor 33. Jakarta.

Ratmono, D. \& Mahfud, S. (2015). Akuntansi keuangan daerah berbasis akrual. Edisi Pertama. Yogyakarta : UPP STIM YKPN.

Rudianto. (2012). Pengantar akuntansi adaptasi IFRS. Jakarta: Erlangga.

Sidik, S. (2019). Pengadaan Barang dan Jasa Pemerintah Dikorupsi. 10 November 2019 (16:39).

https://www.cnbcindonesia.com/news/20191110163518-4-114102/pengadaan-barangjasa-pemerintah-rp1153-t-rp200-t-dikorupsi

Sujarweni, V. W. (2015a). Akuntansi sektor publik. Yogyakarta: Pustaka Baru Press.

Sujarweni, V. W. (2015b). Sistem akuntansi. Yogyakarta: Pustaka Baru Press.

Tuanakotta, T. M. (2015). Audit kontemporer. Jakarta: Salemba Empat.

Warren, C. S. Reeve, J. M dan Duchac, J. E. (2015). Pengantar akuntansi adaptasi Indonesia. Jakarta: Salemba Empat. 